\title{
AKTIVNA I PASIVNA EUTANAZIJA: DA LI SU RAZLIKE NJIHOVOG PRAVNOG STATUSA PRAVNO UTEMELJENE?
}

\section{UOPŠTENO O EUTANAZIJI}

Reč eutanazija potiče iz grčkog jezika i označava bezbolnu, laku smrt „eu“, dobra, „thanatos", smrt. Opšteprihvaćena definicija ne postoji, a pojam eutanazija obuhvata širok krug činjenja i nečinjenja koji za cilj imaju istu posledicu: skraćivanje muka i patnji terminalnim pacijentima, odnosno olakšavanje puta do neminovne posledice - smrti. Sam pojam eutanazija obuhvata aktivnu i pasivnu eutanaziju. Aktivna se sastoji od direktnog ili indirektnog činjenja, koje za posledicu ima namerno izazvanu smrt pacijenta, ili od pomoći u samoubistvu. Pasivna eutanazija se sastoji od nečinjenja određenih radnji koje bi pacijentu produžile život, ali i patnje, kao što su, na primer, odbijanje medicinskog tretmana ili isključivanje aparata za veštačko održavanje života. Pored podele na aktivnu i pasivnu, razlikujemo i voljnu i „nevoljnu“ (non-voluntary) eutanaziju. Prva se sprovodi na izričit zahtev pacijenta, dok se druga sprovodi nad licima koja ne mogu izraziti svoju volju jer su npr. u trajnom vegetativnom stanju, ili su u pitanju bebe ili lica sa nisko razvijenom inteligencijom. Takođe, poznat je i pojam „indirektna“ eutanazija, sprovođenje medicinskog tretmana lekovima protiv bolova čija upotreba za posledicu može imati ubrzanje smrti pacijenta.

\section{PraVNi STATUS AKTIVNE I PASIVNE EUTANAZIJE: ZAKONODAVNO UREĐENJE U SRBIJI I SVETU}

Dok je u većini zakonodavstava pasivna eutanazija legalizovana u vidu prava pacijenta na odbijanje tretmana, pozivajući se na pravo na samoodređenje kao izvor prava na odbijanje tretmana, aktivna eutanazija je zabranjena u većini zemalja, izuzev Holandije, Švajcarske, Belgije, Kolumbije i Japana. Američke federalne države Oregon, Vašington i Montana, kao i Albanija i Luksemburg ne inkriminišu pomoć u samoubistvu. Zakonodavstvo Republike

* Studentkinja Pravnog fakulteta Univerziteta Union u Beogradu 
Srbije propisuje da aktivna eutanazija povlači krivičnu odgovornost. Krivični zakonik Republike Srbije iz 2006. godine uvodi poseban oblik privilegovanog krivičnog dela ubistva: lišenje života iz samilosti, tj. ubistvo iz milosrđa ${ }^{1}$. Radnja izvršenja dela je ista kao i radnja ubistva, ali naročito subjektivno obeležje jeste motiv samilosti pod kojim i radnja krivičnog dela mora biti izvršena, a propisana kazna je blaža nego za ubistvo. Uslovi koji pored motiva samilosti moraju biti ispunjeni jesu punoletstvo bolesnog lica, postojanje neizlečivog fizičkog oboljenja i izvesnost smrtnog ishoda. Krug lica koji mogu biti izvršioci ovog krivičnog dela zakon ograničava na najbliže srodnike, prijatelje i, izuzetno, na zaposleno osoblje u medicinskim ustanovama. Psihičko zdravlje lica koje zahteva da bude lišeno života mora biti apsolutno očuvano. Otvoreno je pitanje da li se radnja ovog dela može preduzeti i nečinjenjem. Ako se osvrnemo na krivično pravo, videćemo da radnju izvršenja može predstavljati svaka delatnost kojom se izaziva posledica dela. Radnja krivičnog dela se sastoji u određenom ljudskom ponašanju. Ponašanje ne započinje samim voljnim aktom, već na njega deluje svest kojom čovek stvara planove koje ostvaruje kasnijim delovanjem. Na određeno ponašanje, činjenje ili nečinjenje, čoveka pokreću motivi čiji su pokretači osećaji. Imajući u vidu da je čovek racionalno biće i da svoje ponašanje određuje ciljevima koje želi postići i svešću o uzročnoj povezanosti određenog ponašanja i posledice izazvane tim ponašanjem, radnja krivičnog dela je uslovljena ciljem koji učinilac nastoji da postigne preduzimanjem te radnje. ${ }^{2}$ Imajući ovo u vidu, ostaje nedorečeno da li je i radnjom nečinjenja moguće izvršiti krivično delo ubistva iz milosrđa. Ako je odgovor potvrdan, to bi značilo inkriminaciju određenih oblika pasivne eutanazije.

Takođe, i pomaganje u samoubistvu je krivično delo u Republici Srbiji. Krivični zakonik inkriminiše pomaganje u samoubistvu nevezano da li je delo izvršeno ili je ostalo u pokušaju ${ }^{3}$. Nijedan propis u Republici Srbiji ne daje jasnu definiciju niti izričitu zabranu eutanazije, dok Kodeks profesionalne etike Lekarske komore Srbije izričito zabranjuje eutanaziju i smatra je lažnim humanizmom i u suprotnosti sa medicinskom etikom ${ }^{4}$. Ista odredba propisuje da će lekar uvažiti pravo pacijenta na odbijanje tretmana, odnosno kako je formulisana u Etičkom kodeksu „lekar će uvažiti želju dobro informisanog, neizlečivo obolelog bolesnika o veštačkom produženju njegovog života izraženu pri punoj svesti“. Etički kodeks propisuje i odnos prema umirućem pacijentu i njegovoj porodici, propisujući pravo na pomoć, negu i ljudski odnos, olakšanje u trpljenju i preduzimanje svih smislenih mera lečenja. Lekar je dužan da umirućem pacijentu obezbedi uslove za dostojanstvenu smrt, pruži svu pomoć u granicama svog delovanja koji omogućuju pacijentu da umre

1 Krivični zakonik Republike Srbije, 2006, član 117.

2 Nataša Mrvić-Petrović, Krivično pravo - Opšti i posebni deo, Beograd 2008.

3 Krivični zakonik Republike Srbije, 2006, član 119.

4 Kodeks profesionalne etike lekarske komore Srbije, 2007, član 62. 
olakšano, ali prirodnim putem. To dovodi do zaključka da bi ubrzanje smrti ubrizgavanjem lekova protiv bolova, čija količina može dovesti do ubrzanja umiranja, predstavaljalo u ovom slučaju radnju krivičnog dela, a ne olakšanje u trpljenju bolova u vidu standardnog medicinskog tretmana umirućeg pacijenta.

Pasivna eutanazija je u Republici Srbiji legalizovana 2005. godine, usvajanjem Zakona o zdravstvenoj zaštiti. Tim zakonom se predviđa da pacijent ima pravo da odbije predloženu medicinsku meru i u slučaju kada se time spasava ili održava njegov život ${ }^{5}$. Lekar se uzdržava od pružanja daljeg medicinskog tretmana i omogućava pacijentu da umre prirodnim tokom. Pravo na odbijanje tretmana svoj osnov crpi iz prava pacijenta na samoodređenje -autonomiju, što čini pravni osnov legalizacije eutanazije. Pasivna eutanazija je legalizovana pomoću pravne fikcije da odbijanje tretmana kojim se spasava ili produžava život nije samoubistvo i da lekar ne izaziva smrt pacijenta, već on umire od posledice bolesti a ne od posledice radnje lekara ${ }^{6}$.

Osnov razlikovanja pasivne od aktivne eutanazije je put kojim se stiže do posledice - smrti lica. Da li je smrt izazvana prirodno, kao posledica bolesti ili je veštački prouzrokovana radnjom pacijenta ili trećih lica? Nije pitanje samo subjekta koji donosi odluku o prestanku lečenja ili o upotrebi medicinskih sredstava kojima se okončava život, jer zakonodavstvo je nedvosmisleno - odluku mora doneti pacijent, ako je u svesnom stanju, a lekar, odnosno članovi porodice pacijenta i sud, u zavisnosti od države u kojoj se pacijent nalazi, ako je pacijent u trajnom vegetativnom ili komatoznom stanju. Glavni kriterijum po kojem zakonodavstva razlikuju aktivnu od pasivne eutanazije jeste upravo sam čin, odnosno radnja kojom se smrt prouzrokuje. Ako smrt nastupa kao posledica bolesti, nema radnje krivičnog dela, jer nema radnje izvršenja, čak iako možemo pretpostaviti da se i nečinjenjem ostvaruje ista posledica. Kod aktivne eutanazije, glavni argument zbog kojeg je ona inkriminisana u većini zakonodavstava jeste taj da se radnjom lekara, trećih lica i samog pacijenta prouzrokuje smrt, veštački, iako je smrtna posledica neminovna, ovde se život „oduzima veštačkim putem“ te pacijent ne umire prirodno, već je smrt posledica radnje lekara ili drugog lica. Osnov zakonske regulative predstavlja ova uzročno-posledična veza, i pravi se podela na aktivnu i pasivnu eutanaziju, koja je zakonski lakše odrediva nego moralno.

Osvrnuću se na stav Evropskog suda za ljudska prava po kojem je nametnuti medicinski tretman povreda prava na privatnost ${ }^{7}$, stav suda u slučaju Pretty $^{8}$ da pravo na odbijanje tretmana proističe iz prava na samoodređenje,

$5 \quad$ Zakon o zdravstvenoj zaštiti Republike Srbije, 2005, član 33.

6 Violeta Beširević, Bogovi su pali na teme: o ustavu i bioetici, Anali Pravnog fakulteta u Beogradu, br. 2/2006.

$7 \quad$ Evropska konvencija o zaštiti ljudskih prava i osnovnih sloboda, član 8.

8 Pretty $v$ UK, 2346-02, 2002. 
kao aspekt privatnog života. Stav Ustavnog suda Mađarske je sličan - garantuje se pravo na odbijanje medicinskog tretmana pozivanjem na pravo na samoodlučivanje koje proističe iz ustavnog prava na ljudsko dostojanstvo. Za razliku od pasivne, aktivna eutanazija nije izvedena iz prava na samoodlučivanje jer je uzrok smrti radnja trećeg lica a ne samo radnja pacijenta, te nema samoodlučivanja.

Ako se legalizacija aktivne eutanazije ne može izvesti iz prava na samoodređenje i samoodlučivanje, odakle može? Da li pravo na život treba da u sebi sadrži i pravo na „dobru smrt“? Da li se može zagarantovati pravom na ljudsko dostojanstvo, na privatnost, slobodu? Koliko je moralno uplitanje države u osnovno i najviše ljudsko dobro - sam život? Registar opštih prava i sloboda je sačinjen da bi štitio od preteranog uplitanja države u privatnu sferu pojedinca. Da li se propisivanjem zabrane aktivne eutanazije krši pravo na ljudsko dostojanstvo i još nezagarantovano pravo na humanu smrt? Koliko država ima pravo da se meša u život pojedinca koji je izgubio svaki smisao i koji se sastoji samo od patnji? Da li je nasilje ne dozvoliti takvoj osobi da umre, a ne očuvati život po svaku cenu, makar forme radi?

Čini mi se da su ovakvom zakonodavnom regulativom najviše pogođeni oni kojima je pomoć najviše i potrebna - lica koja ne mogu sama sebi prekratiti muke i koja su zavisna od drugih. Možda je jedno od najboljih rešenja prihvaćeno u Oregonu, američkoj federalnoj državi koja je legalizovala pomoć u samoubistvu. Zakon o dostojanstvenoj smrti ${ }^{9}$ predviđa da se tretman koji se primenjuje za okončanje života ne smatra ni samoubistvom, ni pomoći u samoubistvu, niti eutanazijom, ubistvom iz milosrđa ili ubistvom.

Posebno se ističe pravno regulisanje prava pacijenata nesposobnih za rasuđivanje i pacijenata u komatoznom i trajnom vegetativnom stanju. $\mathrm{U}$ slučaju ovih pacijenata krajnju odluku o održavanju pacijentovog života donosi lekar ako je u pitanju pacijent u stanju kome ili trajne vegetacije. Ako je u pitanju lice nesposobno za rasuđivanje, krajnju odluku bi trebalo da donese zakonski zastupnik tog lica, samo lice u meri u kojoj je sposobno da rasuđuje i lekar, ali ostaje nejasno da li zakonski zastupnik ima pravo da odbije medicinski tretman kojim se održava ili produžava život pacijenta ${ }^{10}$. Ako je aktivna eutanazija nedopuštena zbog toga što se radnjom lekara prouzrokuje smrt, zbog tog uzročno-posledičnog odnosa, po kom pravnom osnovu je ovaj oblik dopušten? Ovde je jasno da se smrt prouzrokuje aktivnom radnjom lekara koja se sastoji u isključenju aparata za veštačko održavanje života, a ovo delovanje se opravdava činjenjem u najboljem interesu pojedinca, čime se navodno ne povređuje pravo na samoodređenje pojedinca, odnosno prema Etičkom kodeksu se čak i ne spominje pravo na samoodređenje, već se lekari vode isključivo medicinskim kriterijumima. Ipak, primećuje se određena

9 The Death with Dignity Act.

10 Violeta Beširević, Pravo na dostojanstvenu smrt, Glasnik Advokatske komore Vojvodine, br. 12/2008. 
nelogičnost u zaključivanju zakonodavca, a svakako i nedoslednost. Ako se dopušta lekarima apsolutno pravo odlučivanja o prekidu života pacijenata u trajnom vegetativnom stanju, a ta radnja se opravdava fikcijom o najboljem interesu pacijenta, zar analogno ne bi moglo biti dopušteno i lišenje života iz milosrđa nad pacijentom koji svesno i nedvosmisleno može izraziti svoju volju. Naravno, pacijenti u komi ili trajnom vegetativnom stanju mogu biti u moždanoj smrti, pa se možda čin isključenja sa aparata za veštačko održavanje života ne smatra ubistvom, ali moramo imati u vidu složenost medicinske nauke, težinu utvrđivanja stanja moždane smrti i primere iz prakse gde su se pacijenti budili iz kome posle više godina, čak i kada su ih lekari proglasili moždano mrtvim. U pogledu lica nesposobnih za rasuđivanje, teren postaje još klizaviji jer zakonske odredbe ne daju jasnu definiciju o licima koja su ovlašćena da odlučuju i donose odluke u njihovo ime.

Imajući u vidu temu ovog rada, pokušala sam da odgovorim na pitanje - da li su razlike u pravnom statusu i pravno utemeljene? Jasno je po čemu naše zakonodavstvo pravi razliku između aktivne i pasivne eutanazije, a jasno je i da je osnov inkriminacije uzročna veza između radnje činjenja i posledice. Ali sagledavajući problematiku iz više uglova, čini se da je sama „definicija“ aktivne i pasivne eutanazije diskutabilna, i da je samo određenje po radnji činjenja nedovoljno, jer i pored uzdržavanja od činjenja pri pasivnoj eutanaziji postoji volja i svest o posledici. Iako možda razlike u pravnom statusu nisu potpuno pravno utemeljene, iako postoji određeni broj nedoslednosti, smatram da zakonodavac u Republici Srbiji nije pogrešio što nije legalizovao aktivnu eutanaziju. U državi gde lečenje pacijenta bez njegovog pristanka povlači disciplinsku odgovornost sa kaznom u maksimalnom iznosu od 50.000 dinara, gde je diskutabilno da li će prethodno izražena volja umirućeg pacijenta biti uzeta u obzir, i gde se pacijent uglavnom svodi na objekat, a radnje lekara često ne podležu kontroli ili ozbiljnijim sankcijama, nema mesta davanju dodatnih ovlašćenja i ostavljati širok put lekarskom delovanju bez ikakvog osvrta na posledicu.

Eventualnom legalizacijom otvorilo bi se još mnogo novih pitanja - od toga ko odlučuje o nečijoj smrti do toga ko sve treba da umre. Ovde se rađa mogućnost velikih zloupotreba u ime humanosti. Ako se državi da ovlašćenje da odlučuje čiji život predstavlja patnju ili nije dostojan življenja, dolazimo na polje koje lako može odvesti put negacije humanosti, kao što se u istoriji dešavalo u nacističkoj Nemačkoj, koja je pod izgovorom eutanazije sprovela masovna ubistva nad fizički i mentalno bolesnim licima, protivno njihovoj volji1 ${ }^{11}$. Takođe, postavlja se pitanje ukoliko eutanazija postane legalna, hoće li svaka biti zaista dobrovoljna ili će se ubrzo sprovoditi i bez izričitog pristanka pacijenta. Da li se time daju prevelika ovlašćenja lekarima? U SAD i Velikoj Britaniji zapažena je tendencija da se DNR-nalozi (Do Not Resuscitate) pro-

11 http://www.history.ucsb.edu/faculty/marcuse/classes/33d/33d05/33d05L07Eugenics. htm\#h2. 
izvoljno upisuju u kartone starijih pacijenata, bez njihovog znanja. U SAD, DNR-nalozi se češće koriste za Afroamerikance, lica koja potiču van engleskog govornog područja, lica obolela od HIV-a i za hronične alkoholičare ${ }^{12}$. Ovo upućuje na zaključak da su lekari podložni uticaju stereotipa i da mogu donositi važne odluke rukovodeći se njima.

Takođe se postavlja pitanje da li će određene grupe ljudi - stariji, usamljeni, bolesni, depresivni ili čak mentalno bolesni osećati pritisak da zahtevaju preuranjenu $\mathrm{smrt}^{13}$. Usled pritiska porodice, osećanja beskorisnosti ili tereta, nemogućnosti finansiranja lečenja, možda će se lica lakše odlučivati da prevremeno prekinu svoj život. Postoji i bojazan da će se eutanazija zloupotrebljavati i zarad finansijske dobiti u vidu smanjenja troškova lečenja terminalnih pacijenata.

Uzimajući sve iznesene činjenice u obzir, nespornu ideju humanosti, kao i postojeću zakonodavnu regulativu, kao zaključak se nameće ideja da će se sigurno s vremenom put ka „humanoj smrti“ utemeljiti i usaditi u naše društvo, ali na nekim drugim zakonskim osnovama.

12 http://www.bbc.co.uk/ethics/euthanasia/against/against_1.shtml\#section_4.

13 http://www.bbc.co.uk/ethics/euthanasia/against/against_1.shtml\#section_4. 